\title{
ГЕНДЕРНІ АСПЕКТИ ПІДПРИЄМНИЦЬКОЇ ДІЯЛЬНОСТІ В АГРАРНІЙ СФЕРІ
}

\author{
Соколов Микола Олександрович \\ доктор економічних наук, профресор \\ Сумський національний аграрний університет (м. Суми, Україна) \\ ORCID: 0000-0002-1907-9041 \\ sokolovnikolay55@gmail.com \\ Сухоставець Андрій Іванович \\ кандидат економічних наук, доцент \\ Сумський національний аграрний університет (м. Суми, Україна) \\ ORCID: 0000-0002-4101-4105 \\ 9264374@gmail.com
}

В статті проведено аналіз особливостей підприємницької діяльності жінок в Україні, а саме в аграрній сфрері. У дослідженні виявлено характерні риси, види та форми жіночого підприємництва, визначено основні причини підприємницької активності жінок, а також бар'єри та перешкоди.

Вивчено сучасний стан гендерної рівності в Україні та зазначено, що в 2019 році Україна займала 60 місце з 160 країн світу за показником індексу гендерної рівності, а в українському парламенті питома вага жінок складає 20,8 відсотка, тоді як в європейських кранах цей показник наближається до 50 відсотків, наприклад у Швеції - 47 відсотків, у Іспанії 44 відсотка.

Доведено, що однією з перешкод підприємницької діяльності для жінок в аграрній сфрері є гендерні асиметрії, що виникають в бізнес-середовищі. На даний момент підприємництво в агропромисловому комплексі має свої особливості, які пов'язані з тим, що воно охоплює не тільки саму працю в сільському господарстві, а й працю задля розвитку сільських територій та несільськогосподарське підприємництво.

Обгрунтовано причини необхідності сприяння жіночому підприємництву і запропоновано шляхи розвитку підприємництва в аграрній сффері. Основні перешкоди, які ми вважаємо важливими і які стримують розвиток підприємництва - це: низький рівень розвитку мережі соціальної інфраструктури, що створює додаткове навантаження на жінок; відсутність в напрямках аграрної політики окремих елементів, які б стосувалися підтримки жінок в веденні бізнесу; низька доступність до ринку фрінансово-кредитних послуг та інше.

Вважаємо, що в державних програмах необхідно передбачити окремі заходи які 6 стосувалися підтримки жінокпідприємиів, та які 6 мали дієвий, а не декларативний характер.

Ключові слова: підприємниитво, підприємницька діяльність, гендерна політика, аграрна сфрера.

DOI: https://doi.org/10.32845/bsnau.2019.4.18

Постановка проблеми у загальному вигляді. Підприємницька діяльність містить в собі різні аспекти в тому числі і жіноче підприємництво, яке розвивається в України. Актуальність даної теми пов'язана з формуванням у свідомості суспільства стереотипів, пов'язаних з гендерними аспектами, яке пояснюється соціально-економічним становищем, історичним досвідом відповідно до якого жінка не вважалася такою, що може ефективно займатися бізнесом. Питанням жіночого підприємництва приділяється увага, але незважаючи на це, в нашій країні, воно розвивається суперечливо.

Аналіз останніх досліджень і публікацій. Останніми роками гендерні дослідження просуваються різними шляхами в юридичній, філософській, соціологічні, економічній та інших площинах. Серед основних дослідників розвитку жіночої підприємницької діяльності можна виділити наступних: R. Anker (Anker R., 1997), A. Beller (Beller A., 1982), П. Бурдье (Бурдье П., 2002), Т. Демків (Демків Т., 2013), Т. Іваніна (Іваніна Т., 2012), Е. Лібанова (Лібанова Е., 2007), Н. Ю. Олійник (Олійник Н. Ю., 2015), М. М. Скорик (Скорик М.М., 2017), О. П. Славкова (Славкова О. П., 2018), В. Суковата, (Суковата В., 2001), В.М.Хоменко (Хоменко В. М., 2010), М. В. Школяр, І.Я.Добрянська (Шко-

ляр М. В., Добрянська І. Я., 2017), С. Шовкопляс (Шовкопляс С., 2016).

Незважаючи на значну кількість досліджень залишаються невирішеними питання щодо аспектів розвитку жіночого підприємництва в аграрній сфрері. Тому впровадження гендерних підходів має передбачати обов'язковий вихід за рамки суто кількісних характеристик (зайнятості, активності, професійної придатності). Рівна участь жінок та чоловіків у функціонуванні підприємництва та доступу до розвитку своїх підприємницьких якостей має стати важливим напрямом державної аграрної політики. Проведений аналіз наукових публікацій дозволяє зробити висновок щодо недостатнього вивчення даної проблеми, що потребує нових наукових розвідок в даному напрямку.

Формування цілей статті. 3 огляду на попереднє вивчення рівня розробки даної проблеми, метою нашої роботи стало дослідження окремих аспектів гендерного впливу на підприємницьку діяльність. особливу увагу ми приділили аграрному сектору економіки та ролі жінки в його розвитку.

Методи дослідження. Проведене нами дослідження було здійснено з використанням таких наукових методів як: абстрактно-логічний, за допомогою якого проведено огляд наукової літератури з тематики дослідження, статистичний при виявлення тенденцій в розвитку підприємництва,

Вісник Сумського національного аграрного університету Серія «Економіка і менеджмент», випуск 4 (82), 2019 
порівняння при розгляді питання співвідношення оплати праці жінок та чоловіків, графрічне моделювання при побудові гістограм та метод узагальнення при формулюванні висновків дослідження.

Результати дослідження. На сьогодні гендерна рівність є одним з пріоритетів Організації Об'єднаних Націй $(\mathrm{OOH})$. Фундаментальний принцип Статуту $\mathrm{OOH}$, прийнятий світовими лідерами у 1945 році, називається "рівні права чоловіків і жінок", який захищає та заохочує до дотримання прав жінок у всіх державах (Гендерна рівність - Представництво ООН в Україні, 2019).

3 початку отримання незалежності Україна долучилась до головних міжнародних зобов'язань щодо забезпечення гендерної рівності, включаючи Конвенції про ліквідацію всіх форм дискримінації щодо жінок (CEDAW, 1980) та її Факультативного протоколу, Пекінську декларацію та Платформу Дій (1995); встановила національні законодавчі акти для гендерної рівності, включаючи Державну програму щодо забезпечення рівних прав та можливостей для чоловіків та жінок (до 2016), а також Національний план дій "Жінки, Мир та Безпека" (2016) у якості додатку до Резолюції Ради Безпеки 1325 (Про забезпечення рівних прав та можливостей жінок і чоловіків). Конвенція ООН також містить окрему статтю (ст. 11) про шляхи розв'язання проблем дискримінації жінок під час працевлаштування. У цій статті акцентується увага на тому, що жінки мають однакові права та можливості при прийомі на роботу, а також рівну винагороду за однакові види робіт (Хоменко В. М., 2010).

В першу чергу визначимося з поняттям гендер. Ми приєднуємося до думки Демківа Т., що він являє собою дуже складне багатоаспектне поняття яке розкривається у соціально-фрілософських дослідженнях як соціокультурна та рольова інтерпретація поведінки жінок і чоловіків, як процес набуття соціальності індивідуумів, які народилися в біологічних категоріях чоловіка та жінки, і як політика рівноправ'я і надання чоловікам та жінкам рівних можливостей i механізмів реалізації цих можливостей у інформаційному соціумі (Демків Т., 2013).

В свою чергу комплексний ґендерний підхід (gender mainstreaming) за визначенням економічної і соціальної ради ООН (1997 рік) означає оцінку наслідків для чоловіків та жінок будь-якої планованої дії у сфері законодавства, політики або програм в будь-якій області і на всіх рівнях. Це стратегія інтеграції інтересів чоловіків і жінок в процес розробки, реалізації, моніторингу й оцінки всієї політики і програм в політичній, економічній та соціальній ссрерах так, щоб і чоловіки, і жінки в рівній мірі отримували від цього користь, а нерівність би скорочувалася. Кінцева мета застосування комплексного ґендерного підходу - досягнення ґендерної рівності». (Іваніна Т., 2012).

Іваніна Т. вважає, що комплексний ґендерний підхід передбачає дії, спрямовані на: здійснення ґендерного аналізу 3 метою виявлення фактів нерівності між чоловіками і жінками, які необхідно усунути; $\square$ забезпечення рівних можливостей для всіх і вживання ґендерно-орієнтованих заходів у випадках явно вираженої нерівності; $\square$ ініціювання процесу інституційних змін; 口 розробку ґендерного бюджету; ૧ проведення ґендерного аудиту (Іваніна Т., 2012).

Для встановлення рівності прав на державному рівні було прийнято окремі нормативні документи, які підтверджували рівність прав та свобод чоловіка та жінки.
Так Закон України «Про засади запобігання та протидії дискримінації» від 6 вересня 2012 року № 5207-VI (Про засади запобігання та протидії дискримінації, 2012) визначає організаційно-правові засади запобігання та протидії дискримінації з метою забезпечення рівних можливостей щодо реалізації прав і свобод людини та громадянина. Він забронює пряму і непряму дискримінацію, в тому числі за ознакою статі.

Закон України «Про забезпечення рівних прав та можливостей жінок і чоловіків» від 8 вересня 2005 року N 2866IV (Про забезпечення рівних прав та можливостей жінок і чоловіків, 2005) націлений на досягнення паритетного становища жінок і чоловіків у всіх сферах життєдіяльності суспільства шляхом правового забезпечення рівних прав та можливостей жінок і чоловіків, ліквідації дискримінації за ознакою статі та застосування спеціальних тимчасових заходів, спрямованих на усунення дисбалансу між можливостями жінок і чоловіків реалізовувати рівні права.

Основні засади гендерної політики держави формує Верховна Рада України, зокрема Комітет Верховної Ради України з прав людини, національних меншин та міжнаціональних відносин та Підкомітет з міжнародно-правових питань та гендерної політики Верховної Ради України, які застосовують у законодавчій діяльності принципи забезпечення рівних прав та можливостей жінок і чоловіків, у межах, передбачених Конституцією України; здійснюють парламентський контроль за виконанням законодавчих актів з питань забезпечення рівних прав та можливостей жінок і чоловіків.

Також Наказом Міністерства соціальної політики від 8.06.2012 №345 «Про Експертну раду з питань розгляду звернень за фрактами дискримінації за ознакою статі» створено відповідний орган (Про Експертну раду з питань розгляду звернень за фактами дискримінації за ознакою статі, 2012). Основними завданнями Експертної ради є: розгляд звернень за фактами дискримінації за ознакою статі від органів виконавчої влади, органів місцевого самоврядування, неурядових організацій, громадян з метою надання експертної оцінки та вжиття відповідних заходів; розгляд питань щодо забезпечення рівних прав та можливостей жінок і чоловіків в Україні; підготовка рекомендацій центральним та місцевим органам виконавчої влади, органам місцевого самоврядування, підприємствам, установам та організаціям всіх форм власності, об'єднанням громадян, іншим установам та організаціям щодо усунення виявлених порушень з питань ґендерної дискримінації; підготовка пропозицій щодо внесення змін до актів законодавства з метою їх відповідності принципу забезпечення рівних прав та можливостей жінок і чоловіків, недопущення всіх форм дискримінації за ознакою статі.

Незважаючи на достатню кількість нормативних актів стосовно гендерної рівності на даний момент існують також і перешкоди в розвитку жіночого підприємництва.

Олійник Н.Ю. вважає, що можливості жінок у сфері бізнесу обмежені та вони мають менше можливостей реалізувати свої ділові якості через наявність деяких інституційних бар'єрів та різноманітних перешкод що негативно впливає на їх підприємницьку діяльність, та в свою чергу значно понижує їх самооцінку та прагнення до самореалізації (Олійник Н.Ю., 2015).

На думку деяких дослідників в державних програмах відсутні окремі спеціальні заходи які стосуються вразливих груп жінок, що піддаються множинній дискримінації а в деяких

Вісник Сумського національного аграрного університету

Серія «Економіка і менеджмент», випуск 4 (82), 2019 
нормативних документах мають місце лише декларативні заяви про особливу увагу до сільських жінок (Скорик М.М., 2017)

Досліджуючи розвиток підприємницьких якостей М.В. Школяр та І.Я. Добрянська роблять висновок, що бар'єри у бізнесовій діяльності жінок, не враховуючи більшу їх прив'язаність, порівняно з чоловіками, до сімейних обов'язків, мають переважно уявний характер, спровокований актуалізацією в їх свідомості деяких гендерних стереотипів (Школяр М. В., Добрянська І. Я. , 2017).

Продовжуючи тему необхідно також згадати парадигму П. Бурдь'є щодо економічного, культурного та соціального капіталів підприємця, які на його думку впливають на досягнення ним успіху у підприємницькій діяльності. В межах цієї теорії ним здійснюється спроба з'ясувати, яким чином особисті якості підприємців та зв'язки, якими вони володіють, впливають на їх бізнесову діяльність (Бурдье П., 2002).

Деякі автори наголошують на наявність значних ґендерних диспропорцій на ринку праці на основі аналізу рівня економічної активності та зайнятості населення, проблем жіночого безробіття (Лібанова Е., 2007).

Вчені виявили, що можливі шляхи зменшення соціального навантаження на працюючих, а саме підвищення рівня економічної активності жінок працездатного віку, зокрема, за рахунок розвитку підприємництва. Вони зазначають що не тільки в Україні а й у всьому світі постійно зростає розуміння того, що розширення економічних прав та можливостей жінок буде сприяти стабільному довгостроковому економічному розвитку, скороченню масштабів бідності та забезпечить продовольчу безпеку (Women's economic empowerment: Guidance note, 2013).

Розподіл галузей на «жіночі» та «чоловічі» можна пояснити сформованими поглядами у суспільстві щодо ролі та місця чоловіків та жінок та традиційними уявленнями щодо професій, яка обумовлюється фізіологічним особливостями статі та вимогами до окремих професій.

Існують різні методики розділення сфер занятості за статевою ознакою. Так в працях Р. Анкера наголошується, що в випадку якщо частка зайнятих в галузі чоловіків перевищує 80 \% така галузь вважається чоловічою (Anker R., 1997), А.Баллер до чоловічої галузі відносить ту, яка на 5 \% перевищує частку зайнятих чоловіків (Beller A., 1982).

Ми також погоджуємося із В. Суковатою, яка вважає, що перешкодою для підприємницької активності жінок $є$ те, що в Україні ще на жаль відсутня модель «успішної жінки», яка 6 не перекривалася парадигмою «вдалого заміжжя» (В.Суковата, 2001).

Характеризуючи сучасний стан гендерної рівності в Україні необхідно відзначити, що в 2019 році Україна займала 60 місце з 160 країн світу за показником індексу гендерної рівності (Human Development Report, 2019). В українському парламенті жінки займають 20,8 відсотка, а саме 88 депутатів. Понад 40\% жінок засідають у парламентах відразу декількох європейських країн: Швеції (164 жінки з 349, 47\%), Бельгії (61 жінка з 150, 40,7\%), Португалії (92 жінки з 230, 40\%), Норвегії (70 жінок зі 169, 41,4\%), Іспанії (154 жінки із 350, 44\%), Швейцарії (83 жінки з 200, 41,5\%), Македонії (48 жінок зі 120, 40\%) (Скільки депутатів-жінок у парламентах світу, 2019).

За показниками зайнятості в Україні 46,7 відсотка жінок зайняті проти 62,8 відсотка чоловіків, причому показник гендерного розриву у рівні щомісячної заробітної плати складає 21,2 відсотка.

Окрім цього жінки в Україні на виконання побутових обов'язків витрачають 29 годин на тиждень а чоловіки тільки 15 годин, схожа ситуація з часом проведеним з дітьми, а саме жінки витрачають 49 годин на тиждень а чоловіки лише 22 години. При цьому тривалість життя жінок 76,7 років а чоловіків 67 років.

В 2020 році в українській статистиці відбулися зміни стосовно обліку юридичних осіб, керівниками яких є жінки за організаційно-правовими формами господарювання (таблиця 1).

Таблиця 1

Юридичні особи, керівниками яких є жінки, за організаційно-правовими формами господарювання ( вибрані дані на 1 січня 2020 року)

\begin{tabular}{|l|c|c|}
\hline \multicolumn{1}{|c|}{ Найменування показника } & Всього юридичних осіб & $\begin{array}{c}\text { Частка юридичних осіб, } \\
\text { у яких керівниками є жінки, \% }\end{array}$ \\
\hline Всього & 1350627 & 28,9 \\
\hline з них: & 46929 & 20,47 \\
\hline фермерське господарство & 28071 & 27,14 \\
\hline кооперативи & 1009 & 14,67 \\
\hline сільськогосподарський виробничий кооператив & 1270 \\
\hline
\end{tabular}

Джерело: Опрацьовано автором на основі: http://www.ukrstat.gov.ua/operativ/operativ2020/edrpoy/Gender/Gender0120 u.htm

На жаль немає даних стосовно окремої групи сільськогосподарських підприємств, але з доступних даних можемо зробити висновок про те, що по таким видам підприємницької діяльності як фермерське господарство, сільськогосподарський виробничий кооператив, сільськогосподарський обслуговуючий кооператив частка юридичних осіб, у яких керівниками є жінки складає 20,47 відсотків, 14,67 відсотків,
24,25 відсотків відповідно. Ці дані свідчать про те, що жінки рідко використовують свій підприємницький потенціал.

Аналіз домогосподарств в сільській місцевості за 2018 рік доводить те, що в цьому напрямку жінки розвиваються набагато краще в реалізації своїх підприємницьких здібностей (рис.1). 


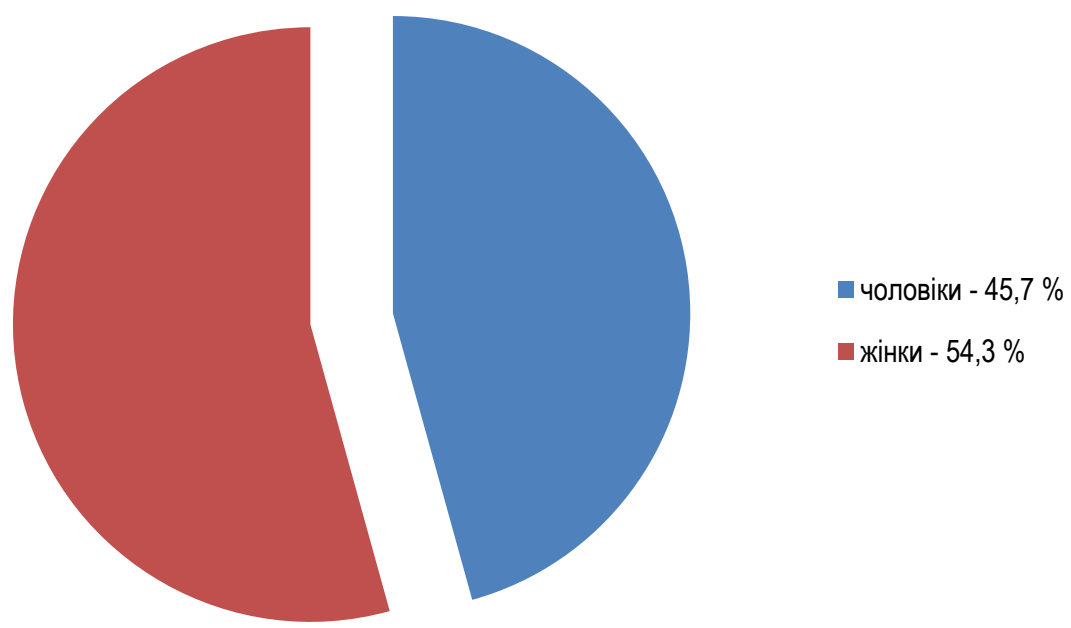

Рис.1. Статевовіковий склад членів сільських домогосподарств у 2018 році

Джерело: опрацьовано автором на основі: Основні сільськогосподарські характеристики домогосподарств у сільській місцевості у 2018 році. http://www.ukrstat.gov.ua/druk/publicat/kat u/2018/zb/07/zb sdhdu2018pdf.pdf

За даним державної служби статистики в 2018 році процентне співвідношення жінок, які очолюють домогосподарства в сільській місцевості 52,7 відсотків очолюють жінки та середній вік таких жінок складає - 62 роки.
Важливим питанням $є$ також освіта жінок які очолюють особисті сільські домогосподарства (таблиця 2). Це дуже актуально в зв'язку з тим, що наявність освіти дозволяє жінкам більш активно приймати участь у підприємництві та розвитку бізнесу.

Таблиця 2

Освітній рівень голів сільських домогосподарств у 2018 році

\begin{tabular}{|c|c|c|}
\hline Найменування показника & Чоловіки & Жінки \\
\hline \multicolumn{3}{|l|}{ Голови домогосподарств, що мають освіту: } \\
\hline повну вищу & 8,5 & 9,6 \\
\hline базову вищу & 1,0 & 1,3 \\
\hline неповну вищу & 11,8 & 16,6 \\
\hline профресійно-технічну & 26,6 & 12,9 \\
\hline повну загальну середню & 34,2 & 30,4 \\
\hline базову загальну середню & 14,2 & 18,4 \\
\hline початкову загальну & 3,4 & 9,9 \\
\hline Голови домогосподарств, що не мають початкової загальної освіти & 0,3 & 0,8 \\
\hline Голови домогосподарств неписьменні & 0,0 & 0,1 \\
\hline
\end{tabular}

Джерело: опрацьовано автором на основі: Основні сільськогосподарські характеристики домогосподарств у сільській місцевості у 2018 році. http://www.ukrstat.gov.ua/druk/publicat/kat u/2018/zb/07/zb sdhdu2018pdf.pdf

Аналіз таблиці показує, що тільки 9,6 відсотків жінок мають повну вищу освіту та 1,3 відсотка базову вищу. Такі показники пояснюються віковою структурою та обмеженим доступом для таких вікових категорій та географфічного розташування до освіти. Сільські жінки, на даний момент складають приблизно 53\% її сільського населення, більшість з яких самотні та мають похилий вік.

Негативним $є$ той факт, що сільські жінки, які зайняті в особистому господарстві не сплачують за себе єдиний соціальний внесок не мають права на соціальне страхування, та відповідно на пенсійне забезпечення. Робота таких осіб в домогосподарствах не зараховується до трудового стажу.

Тому на нашу думку для таких категорій жінок важливим та ефективним буде відкриття своєї справи, що позитивно вплине на розвиток підприємництва. Але на даний момент підприємництво в агропромисловому комплексі має свої особливості, які пов'язані з тим, що воно охоплює не тільки саму працю в сільському господарстві а й розвиток сільських територій та несільськогосподарське підприємництво.
Основні перешкоди, які ми вважаємо важливими і які стримують розвиток підприємництва: відсутність в напрямках аграрної політики окремих елементів, які б стосувалися підтримки жінок в веденні бізнесу; низька доступність до ринку фрінансово-кредитних послуг; низький рівень розвитку мережі закладів соціальної інфраструктури, наприклад дитячих садків, що створює додаткове навантаження на жінок та інше.

В зв'язку з чим, на думку Трофімцевої О. необхідна ефективна підтримка малого бізнесу та створення умов для його швидкого розвитку, через стимулювання виробництва нішевих культур, сімейного фермерства і кооперації до формування нових засад культури ведення бізнесу в країні та боротьби з гендерними кліше (Трофімцева О., 2019 )

Одним з видів підприємницької діяльності, де могли б зарекомендувати себе жінки як справжні господині це сільський зелений туризм. Він може бути джерелом поповнення бюджету об'єднаної територіальної громади та місцем пра- 
цевлаштування для сільських жінок. На думку Вікторії Шаповалової власниці садиби сільського зеленого туризму "Козацька січ" у селі Констянтинівка Недригайлівського району Сумської області починати свій бізнес не просто, потрібні ресурси. Вікторія Шаповалова зазначила, що ідея створення бази зеленого туризму виникла у її батька і спочатку не носила бізнесового характеру. В першу чергу була надія зберегти село, те місце, де всі люблять відпочивати, красива природа, можливість поспілкуватися з дідусями і бабусями (Шовкопляс С., 2016).

Втілити в життя цю ідею нам допоміг кластер «Посулля», об'єднання підприємців Недригайлівщини. У рамках кластеру активні люди підтримують один одного. Скажімо, туристи, які відвідують нашу садибу, можуть переночувати у готелі, що належить вже іншим бізнесменам. Починати бізнес, загалом, непросто, бо це вимагає значних фінансових ресурсів. Потрібен час, потрібні люди, які б працювали, а в селі таких важко знайти, бо там живе лише 10 осіб. Отож, в роботі залучаються жителі районного центру, і вся родина, звичайно ж, працює, підприємницька діяльність відбувається вже шостий рік. 3'явилися вже й постійні клієнти, співпрацюємо 3 одним із сумських туристичних агентств. Загалом, зелений туризм - це доволі перспективний напрямок роботи, а ще відносно дешевий вид відпочинку. Звичайно, ми ще маємо працювати над рівнем обслуговування, і розширюватися, пропонувати гостям щось нове. Мені здається, що при належній підтримці з боку обласної влади саме зелений туризм на Сумщині міг би стати основою для економічної успішності регіону

На допомогу жінкам-підприємцям може прийти тісна співпраця 3 кластерами, об'єднаннями підприємців, територіальною громадою, обласною державною адміністрацією

Висновки. Ми вважаємо, що дослідження гендерної проблематики у теоретичному та емпіричному аспектах повинно супроводжуватися використанням комплексного підходу для виявлення варіативних причин впливу гендерних питань, що й виступає, на даний момент, перспективою подальших досліджень.

Підсумовуючи вищенаведене, можна сказати, що дослідження гендерної проблематики в дослідженні підприємництва в аграрній сфері достатню важливі вважаючи, що дві складові цього поняття, а саме середньої тривалості життя та розподілу зайнятості населення за професійними групами. Ми вважаємо що жінки є потенціальними підприємцями особливо у сфрерах несільськогосподарської зайнятості та сферах пов'язаних із дрібнотоварним виробництвом.

Подальші дослідження ми пов'язуємо з розробкою пропозицій щодо захисту прав жінок на реалізацію своїх підприємницьких здібностей при розробці стратегій розвитку підприємництва, а саме необхідності враховувати питання забезпеченості гендерної рівності.

\section{Список використаної літератури:}

1. Anker R. (1997). Theories of Occupational Segregation by Sex: An Overview. International labor Review. 136 p.

2. Beller A. (1982) Occupational Segregation by Sex: Determinants and Changers. Journal of Human Resources. vol. 17. Issue 3, pp.371-392. kapitala.

3. Bourdieu P. (2002). Forms of capital. Economic sociology. Issue 5 (3). Available at: http://cyberleninka.ru/article/n/formy-

4. Demkiv T. (2013) Transformation of moral priorities on the way to gender equality. Bulletin of the Precarpathian University. Philosophical and psychological sciences. Issue. 17. pp. 73-77.

5. Gender Equality - UN Office in Ukraine. Available at: http://www.un.org.ua/ua/nasha-robota/gender (Accessed 02.02.2019).

6. How many female deputies in the parliaments of the world. Available at: https://www.slovoidilo.ua/2020/02/12/infografika/polityka/skilky-deputativ-zhinok-parlamentax-svitu. (Accessed 02.02.2019).

7. Human Development Report 2019. Beyond income, beyond averages, beyond today: Inequalities in human development in the 21st century. Published for the United Nations Development Program (UNDP). 352p.

8. Ivanina T. (2012) Gender aspects of budgeting at the local level. A practical guide. $36 p$

9. Khomenko V.M. (2010). Substantiation of theoretical bases of the organization of administrative activity taking into account a gender aspect. Management, economics and quality assurance in pharmacy. № 6. pp. 22-27.

10. Libanova E. (2007). Gender differentiation of incomes of the population of Ukraine. Politics and time. № 3. pp. 36-41.

11. Oliynyk N.Y. (2015) Women's entrepreneurship in Ukraine: features and prospects. Financial space. № 2. (18). pp.408413.

12. On ensuring equal rights and opportunities for women and men. Law of Ukraine № 2866-15 of January 7, 2018. Available at: http://zakon2.rada.gov.ua/laws/show/2866-15 (Accessed 02.02.2019).

13. On the Expert Council for Consideration of Appeals on the Facts of Discrimination on the Grounds of Sex. Order of the Ministry of Social Policy dated 8.06.2012 №345. Available at: https://zakon.rada.gov.ua/rada/show/v0345739-12 (Accessed 02.02.2019).

14. On the principles of preventing and combating discrimination. Law of Ukraine of September 6, 2012 № 5207-VI. Available at: https://zakon.rada.gov.ua/laws/show/5207-17 (Accessed 02.02.2019).

15. Shkolyar M.V., Dobryanskaya I. Y. (2017). Gender dimension of entrepreneurial activity. Science and Education a New Dimension. Humanities and Social Sciences. Issue (20). pp.77-80. Available at: www.seanewdim.com. (Accessed 02.02.2019).

16. Shovkoplias S. (2016). When will the new era of entrepreneurship come? Business news. Bulletin of the Chamber of Commerce and Industry. №4 (116). pp. 4-6.

17. Skorik M.M. (2017) Gender discrimination in access to work and services: an assessment of the state of implementation of Ukraine's EU Council anti-discrimination Directives. Analytical research. K. 78 p. 
18. Slavkova OP (2018) Gender aspects of sustainable rural development. Economic, political and cultural aspects of Ukraine's European integration in the context of globalization challenges: materials of the reports of the International scientific-practical conference (Uzhhorod, April 16-17, 2018). Helvetica Publishing House, P.218 -220.

19. Socio-demographic characteristics of Ukrainian households in 2018. State Statistics Service of Ukraine, 2018. 86 Available at: http://www.ukrstat.gov.ua/druk/publicat/kat_u/2018/zb/07/zb_sdhdu2018pdf.pdf. (Accessed 02.02.2019).

20. Sukovata V. (2001). Stereotypes of entrepreneurship in the mass consciousness: gender analysis. Sociology: theory, methods, marketing. № 2. P.131-143.

21. The Constitution of Ukraine was adopted at the fifth session of the Verkhovna Rada of Ukraine on June 28, 1996. Available at: https://zakon.rada.gov.ua/laws/show/254\%D0\%BA/96-\%D0\%B2\%D1\%80. (Accessed 02.02.2019).

22. The main agricultural characteristics of households in rural areas in 2018. Available at: http://www.ukrstat.gov.ua/druk/ publicat/ kat_u/2018/zb/07/ zb_sdhdu2018pdf.pdf. (Accessed 02.02.2019).

23. Trofimtseva O. (2019) Gender asymmetry and women's entrepreneurship. Will there be a takeoff in Ukraine? Economic truth. Available at: https://www. althoughda.com.ua/rus/columns/2019/11/19/653893/ (Accessed 02.02.2019).

24. Women's economic empowerment: Guidance note. Available at: https://www.enterprise-development.org/wp-content/uploads/Womens_Economic_Empowerment.pdf (Accessed 02.02.2019).

Nikolay Sokolov, Dr, professor, Sumy National Agrarian University (Sumy, Ukraine)

Andrii Sukhostavets, PhD, Associate Professor, Sumy National Agrarian University (Sumy, Ukraine)

Gender aspects of entrepreneurial activity in the agricultural sphere

In the article the analysis of features of business activity of women in Ukraine, namely in the agrarian sphere, is carried out. In the research characteristic features, types and forms of women's business are revealed, the main reasons for women 's entrepreneurship and also barrier and obstacles are defined.

The present condition of gender equality in Ukraine is studied and it is specified that in 2019 Ukraine took the 60th place from 160 countries of the world on an indicator of the index of gender equality and in the Ukrainian Parliament the specific weight of women is 20.8 percent whereas in the European countries this indicator comes nearer to 50 percent, for example, in Sweden - 47 percent, Spain has 44 percent.

It is proven that one of the obstacles of business activity of women in the agrarian sphere is the gender asymmetries arising in business environment. At the moment business in agro-industrial complex has the features which are connected with the fact that it covers not only the work in agriculture itself but also the development of rural territories and non-agricultural business.

The reasons of the necessity of the assistance of women's business are justified, and the ways of development of business in the agrarian sphere are offered. The main obstacles which we consider important and which constrain business development are: a low level of development of network of social infrastructure that creates additional loading for women; absence of separate elements in the directions of agrarian policy which would concern support of women in running business; low availability to the market of financial and credit services and others.

We consider that in state programs it is necessary to provide some actions which would concern support of businesswomen and which would have effective but not declarative character.

Key words: entrepreneurship, entrepreneurial activity, gender policy, agrarian sphere.

Дата надходження до редакції: 20.10.2019 р. 